system, a survey of the information and physical environment, user environment, testing for vulnerabilities.

During the audit, a protocol of threats and vulnerabilities of the enterprise's information security is kept. Based on the audit protocol, an audit report is prepared, which indicates the level of effective functioning of the working cycle, the degree of vulnerability of information networks, and reflects the measures to protect the information of the enterprise. In addition, recommendations are provided for the modernization and development of the enterprise information system, as well as improving the efficiency of its functioning.

Conducting a qualified audit of the information security of an enterprise and implementing a set of measures to protect information resources according to the recommendations developed as a result of such an audit, gives confidence in the security of the information and telecommunications system for a certain period.

УДК 336.226.2

DOI: $10.35340 / 2308-104 X .2021 .90-1-07$

\section{ОСОБЛИВОСТІ ЗЕМЕЛЬНОГО ОПОДАТКУВАННЯ В УКРАЇНІ}

СЕМКОВА Л. В., кандидат економічних наук, доцент Маріупольський гуманітарний університет

\section{FEATURES OF LAND TAXATION IN UKRAINE}

\author{
SEMKOVA L., \\ $\mathrm{PhD}$ in Economics, \\ Associate Professor \\ Mariupol State University
}

В статті визначено сутність та економічний зміст земельного оподаткування. Зазначено, що земельний податок є одним з джерел поповнення місцевих бюджетів та державного бюджету. Визначено осіб платників земельного податку та терміни сплати даного виду податку. Розглянуто на прикладі Донецької області плату земельного податку відповідно до встановлених норм у 2021 році. Наведено алгоритм розрахунку земельного податку. Охарактеризовано особливості та правила складання декларації з сплати за землю. Визначено категорії осіб та категорії земель, які звільнено від сплати земельного податку.

Ключові слова: земля, земельний податок, місцевий та державний бюджет, алгоритм оподаткування, декларація, пільги.

В статье определена сущность и экономическое содержание земельного налогообложения. Указано, что земельный налог является одним из источников пополнения местных бюджетов и государственного бюджета. Определены плательщики земельного налога и сроки уплаты данного вида налога. Рассмотрено на примере Донецкой области плату земельного налога в соответствии с установленными нормами в 2021 году. Приведен алгоритм расчета земельного налога. Охарактеризованы особенности и правила составления декларации по плате за землю. Определены категории лиц и категории земель, которые освобождаются от уплаты земельного налога.

Ключевые слова: земля, земельный налог, местный и государственный бюджет, алгоритм налогообложения, декларация, льготы. 
The article defines the essence of the economic content of land taxation. It is noted that the land tax is one of the sources of replenishment of local budgets and the state budget. The persons of land tax payers and terms of payment of this type of tax are determined. The payment of land tax in accordance with the established norms in 2021 is considered on the example of Donetsk region. The algorithm of land tax calculation is given. Features and rules of drawing up a declaration of payment for land are described. Categories of persons and categories of lands that are exempt from land tax are determined.

Keywords: land, land tax, local and state budget, taxation algorithm, declaration, benefits.

Постановка проблеми. Податкова політика будь-якої держави $€$ формоутворюючим елементом фінансової системи країни. Від ії інструментів та механізмів функціонування залежить ефективність економічного розвитку всіх форм господарювання. Враховуючи, що земля - це найцінніше багатство країни, земельне оподаткування відіграє ключову позицію у загальній державній податковій системі. На тлі значних земельних реформ, відкриттям земельного ринку, стає досить актуальним дослідження особливостей національного оподаткування, яке дасть можливість сформувати уявлення про державну політику у сфері управління земельними ресурсами.

Аналіз останніх досліджень і публікацій. Враховуючи важливість та актуальність питання щодо земельного оподаткування, багато науковців та експертів досліджують особливості та механізми сплати земельного податку, а саме: Павалій А. [1], Борзенкова О. [3], БілоусОсінь Т., Койчева О. [4], Тронько О. [5], Децюра С. [6], Брикайло Ю. [9].

Метою статті є дослідження особливостей та механізму сплати земельного податку в Україні, відповідно чинному законодавству.

Виклад основного матеріалу. Система земельного оподаткування в Україні почала формуватися у 1992 р. з прийняттям Закону України «Про плату за землю», в якому зазначалося, що плата за землю належить до загальнодержавних податків та стягується у вигляді земельного податку або орендної плати. Вже у 1997 р. набрала чинності нова редакція цього закону, де було змінено ставки земельного податку, порядок справляння цієї плати, пільги щодо оподаткування землі та відповідальність платників. Наразі основним законодавчим актом, що регламентує земельні відносини у сфері оподаткування, є Податковий кодекс України [1].

У п. 14.1.147 ст. 14 Податкового кодексу України закріплено, що плата за землю - обов'язковий платіж у складі податку на майно, що справляється у формі земельного податку та орендної плати за земельні ділянки державної і комунальної власності [2].

Одним 3 дієвих інструментів впливу держави на земельні правовідносини $€$ плата за землю, яка $€$ також джерелом наповнення місцевих бюджетів України. Цей податок має значні переваги як у фіскальному, так і в регулюючому аспектах:

1. Земельну ділянку неможливо приховати, тому не існує можливості ухилення від ії сплати.

2. Земельний податок повністю сплачується землевласниками і не може бути перекладений на будь-якого іншого платника.

3. Земля як об'єкт оподаткування легко піддається точному обліку, що, в свою чергу, створює умови для точного визначення суми податкового зобов'язання на підставі достовірних даних про об'єкт 
оподаткування за звітний період. Адже крім грошової оцінки, об'єкт оподаткування має фізичний вимір, що спрощує його облік і визначення суми платежу.

4. При сплаті податку за землю забезпечується стимулювання власників землі та землекористувачів до більш продуктивної праці, оскільки розмір цього платежу залежить лише від розміру земельної ділянки, якою володіє його платник, а не від ефективності ії використання.

5. Цей вид платежу як інструмент державного регулювання може сприяти ефективному користуванню землі - основного природного багатства, оскільки їі платність змушує землевласника чи землекористувача отримувати дохід від використання земельних ділянок (бо це не призводить до зростання податкових платежів).

6. При цьому ставки плати за землю визначаються за стабільною кадастровою оцінкою земель від іiї категорії, угідь, груп ґрунтів і переглядаються лише у разі зміни цін та інших причин. Отже, встановлюючи кадастрові диференційовані ставки залежно від якості й місцезнаходження земельної ділянки, держава таким чином здійснює регулювання розподілу капіталу на території країни та їі регіонів. Крім того, плата за землю $€$ інструментом регулювання і територіального розміщення продуктивних сил у країні. Так, в індустріально перенасичених регіонах можуть встановлюватися підвищені ставки плати за землю. А для регіонів, які потребують додаткової підтримки 3 боку держави, навпаки, встановлюється пільгові [3].

Доходи від оподаткування землі $€$ невід'ємним джерелом наповнення державного та місцевого бюджетів. При цьому, можливим $\epsilon$ застосування різних підходів до цього. Загалом, земельне оподаткування може бути виражено через такі категорії, як: податок на землю (capitalprofittax), податок на купівлю та реєстрацію землі (purchaseandregistrationtax), податок за користування землею ("realestatetax"). Усі зазначені види земельного оподаткування реалізуються в Україні з врахуванням особливостей, яких обумовлено діючою правовою системою та розвитком суспільних відносин [4].

Економічний зміст земельного оподаткування можна розглянути через призму наступних функцій:

1. Функція стимулювання - потреба у раціональному використанні земельної ділянки.

2. Функція регулювання - покликана задля створення максимально вигідних умов та можливостей господарювання.

3. Функція фіскальна - врегулювання грошового вираження земельних відносин [5].

Відповідно до чинного законодавства платниками земельного податку $€$ власники земельних ділянок, часток (паїв), а саме:фізособи (громадяни), юридичні особи, фізособи-підприємці.

Термін сплати земельного податку для фізичних та юридичних осіб відрізняється, так юридичні особи та фізичні особи підприємці повинні сплачувати даний податок щомісячно, упродовж 30 календарних днів, а фізичні особи (громадяни) - упродовж 60 днів 3 дня вручення податкового повідомлення-рішення.

Розглянемо на прикладі Донецької області плату земельного податку відповідно до встановлених норм (рис. 1). 


\begin{tabular}{|c|c|}
\hline \multicolumn{2}{|c|}{ СПЛАТА ЗЕМЕЛЬНОГО ПОДАТКУ } \\
\hline $\begin{array}{l}\text { За земельні ділянки, НГО яких } \\
\text { проведена: } \\
\text { - не більше 3\% від НГО; } \\
\text { - для земель загального } \\
\text { користування - не більше 1\% від } \\
\text { НГО; } \\
\text { - для сільськогосподарських угідь } \\
\text { - О,3\% -1\% від НГО; } \\
\text { - для лісових земель - не більше } \\
\text { 1\% від НГО. }\end{array}$ & $\begin{array}{l}\text { За земельні ділянки, НГО яких } \\
\text { не проведена: } \\
\text { - за ділянки, розташовані в межах } \\
\text { населених пунктів, або за їх } \\
\text { межами - не більше 5\% від НГО по } \\
\text { області; } \\
\text { - для сільськогосподарських угідь } \\
\text { - 0,3\% -5\% від НГО по області; } \\
\text { - для лісових земель - не більше } \\
\text { 0,1\% від НГО по області }\end{array}$ \\
\hline
\end{tabular}

Порядок обчислення земельного податку $=$ Площа земельної ділянки * НГО ${ }^{*}$ Ставку податку ${ }^{2}$

${ }_{1}^{1}$ НГО ріллі по Донецькій області на 2021 рік складає 32111 грн.

${ }^{2}$ Ставки та пільги визначаються органами місцевого самоврядування, ставки розміщенні на субсайті ГУ ДПС у Донецькій області.

${ }^{*}$ Сформовано автором на базі джерела [7]

Рис. 1. Сплата земельного податку у Донецькій області на 2021 р.

Алгоритм розрахунку земельного податку залежить від правил визначення бази оподаткування землі, а саме від того, чи проведена нормативно грошова оцінка (НГО) землі, чи ні. Так, якщо [6]:

- НГО земель проведена, то податок розраховується як добуток площі землі (у га), НГО одиниці площі, проіндексованої станом на початок року (у грн), та ставки податку (у \%);

- НГО земель не проведена, то податок визначають як добуток площі (у кв. м або га) та ставки (у грн за 1 кв. м або га). При цьому ставка податку визначається, опираючись на НГО одиниці площі ріллі по області.

Для того, щоб юридичним особам відзвітувати щодо земельного податку необхідно подати декларацію, яка затверджена наказом Міністерства фінансів від 16.06.2015 р. № 560.

та у табл. 2.

Особливості та правила складання декларації наведено у табл. 1

Порядок заповнення розділу I декларації з плати за землю[6]

\begin{tabular}{|c|l|l|}
\hline $\begin{array}{c}\text { Номер } \\
\text { колонки }\end{array}$ & Назва колонки & \multicolumn{1}{|c|}{ Правило заповнення } \\
\hline 2 & Категорія & Зезначають чотиризначний код (формат XX.XX) \\
& земельних & щодо категорії / цільового призначення земель. \\
& & Цей код має відповідати інформації, зазначеній \\
& & у правовстановлюючих документах на \\
& & земділянку або довідці про НГО. Шукати такі \\
& коди слід у Класифікації земель.
\end{tabular}




\begin{tabular}{|c|c|c|}
\hline & & Продовження табл. \\
\hline $3-4$ & $\begin{array}{l}\text { Документи, які } \\
\text { засвідчують/ } \\
\text { підтверджують } \\
\text { право власності/ } \\
\text { користування }\end{array}$ & $\begin{array}{l}\text { Відображають інформацію, } 8 \text { взяту } \\
\text { правовстановлюючих документах на земділянку, } \\
\text { а саме: } \\
\text { - у к. } 3 \text { вказують вид права власності : } 1 \text { - } \\
\text { власність, } 2 \text { - постійне користування; } \\
\text { - у к. } 4 \text { зазначають серію та номер документа, } \\
\text { який підтверджує право власності чи } \\
\text { користування землею, тобто серію і номер } \\
\text { держакту на землю або свідоцтва про право } \\
\text { власності. }\end{array}$ \\
\hline $5-6$ & $\begin{array}{l}\text { Державна } \\
\text { реєстрація прав } \\
\text { власності/ } \\
\text { користування (у } \\
\text { разі наявності) }\end{array}$ & $\begin{array}{l}\text { Тут вказують інформацію про реєстрацію } \\
\text { речових прав на землю. Беруть їх зі Свідоцтва } \\
\text { про реєстрацію речових прав на нерухомість. } \\
\text { У к. } 5 \text { вказуєте дату реєстрації у форматі «дві } \\
\text { цифри місяця, чотири цифри року". } \\
\text { У к. } 6 \text { зазначаєте номер запису, під яким було } \\
\text { внесено запис до Держреєстру прав власності } \\
\text { на нерухоме майно. }\end{array}$ \\
\hline 7 & $\begin{array}{l}\text { Кадастровий } \\
\text { номер земельної } \\
\text { ділянки (у разі } \\
\text { наявності) }\end{array}$ & $\begin{array}{l}\text { Зазначають кадастровий номер своєї } \\
\text { земділянки. Його беруть із правовстановлюючих } \\
\text { документів на земділянку. Кадастровий номер } є \\
\text { дев'ятнадцяти значним. }\end{array}$ \\
\hline $8-9$ & $\begin{array}{l}\text { Площа земельної } \\
\text { ділянки }\end{array}$ & $\begin{array}{l}\text { Тут вказуєте дані про площу конкретної } \\
\text { земділянки. Такі дані наводять або у гектарах з } \\
\text { чотирма десятковими знаками (к. 8), або в } \\
\text { метрах квадратних із двома десятковими } \\
\text { знаками (к. 9). Де її брати, див на початку статті. } \\
\text { Заповнювати слід тільки одну з цих колонок. Яку } \\
\text { саме, вирішує сам платник } \\
\text { На наш погляд, слід вибрати ту одиницю виміру, } \\
\text { щодо якої наведено розмір НГО у довідці (витягу) } \\
\text { про розмір НГО. Тоді у вас буде менше мороки із } \\
\text { розрахунком податку, оскільки не доведеться } \\
\text { морочитися з переведенням НГО за } 1 \text { кв. м у НГО } \\
\text { за 1 га чи навпаки. }\end{array}$ \\
\hline 10 & $\begin{array}{l}\text { Нормативна } \\
\text { грошова оцінка } \\
\text { одиниці площі } \\
\text { земельної } \\
\text { ділянки (грн) }\end{array}$ & $\begin{array}{l}\text { Вказуєте розмір проіндексованої НГО за } 1 \text { гектар } \\
\text { або 1 кв. м земділянок (у гривнях з двома } \\
\text { десятковими знаками). } \\
\text { Щоб визначити, за } 1 \text { га чи за } 1 \text { кв. м слід вказати } \\
\text { НГО, вам потрібно подивитися на те, в яких } \\
\text { одиницях ви відобразили в декларації площу } \\
\text { землі (заповнили к. } 8 \text { чи к. 9) } \\
\text { Тобто якщо площу ви зазначили у гектарах } \\
\text { (заповнили к. 8), то і нГО зазначаємо за } 1 \text { га. } \\
\text { Де її брати і як проводити індексації, читайте на } \\
\text { початку статті. } \\
\text { Зверніть увагу: у цій графі вказуємо НГО не за } \\
\text { всю земділянку, а за одиницю їі площі. }\end{array}$ \\
\hline 11 & $\begin{array}{l}\text { Нормативна } \\
\text { грошова оцінка } \\
\text { одиниці площі } \\
\text { ріллі } \\
\text { Автономній } \\
\text { Республіці } \\
\text { або прим } \\
\text { (грн) області }\end{array}$ & $\begin{array}{l}\text { У цій графі вказують чинну на момент подання } \\
\text { декларації НГО площу ріллі по АР Крим або по } \\
\text { області, на території якої знаходиться земельна } \\
\text { ділянка, за яку сплачується податок. Дані про } \\
\text { НГО відображають з двома десятковими знаками } \\
\text { з урахуванням коефіцієнтів індексації (ст. } 289 \\
\text { ПкУ). } \\
\text { Заповнюють цю графу тільки ті платники, в яких } \\
\text { НГО не проведена. Дізнатися розмір такої НГО } \\
\text { ви зможете у своїй податковій. }\end{array}$ \\
\hline
\end{tabular}


Продовження табл. 1

\begin{tabular}{|c|c|c|}
\hline 12 & $\begin{array}{l}\text { Ставка } \\
\text { (\%) }\end{array}$ & $\begin{array}{l}\text { Зазначаєте ставку податку у відсотках. Берете ії } \\
\text { із рішення місцевого органу влади (ст. } 284 \text { ПКУ). } \\
\text { Про це читайте на початку статті. }\end{array}$ \\
\hline 13 & $\begin{array}{l}\text { Річна сума } \\
\text { земельного } \\
\text { податку }\end{array}$ & $\begin{array}{l}\text { Щоб заповнити цю графу, слід провести нехитрі } \\
\text { арифметичні дії за формулою, наведеною у назві } \\
\text { графи. Розраховуєте податок за такими } \\
\text { формулами: } \\
\text { 1) для земельних ділянок, НГО яких проведена і } \\
\text { НГО визначена: } \\
\text { - за } 1 \text { га: к. } 8 \text { х к. } 10 \text { хк. } 12: 100 \text {; } \\
\text { - за } 1 \text { кв. м: к. } 9 \text { к. } 10 \text { х к. } 12: 100 ; \\
\text { 2) для земельних ділянок, НГО яких не } \\
\text { проведена: } \\
\text { к. } 8 \text { або к. } 9 \text { х к. } 11 \text { х к. } 12: 100 . \\
\text { у цій графі нараховується загальний річний } \\
\text { розмір податку. І попри це, правила заповнення } \\
\text { цієї графи, як для річної, так і для місячної } \\
\text { декларації одні й ті самі. }\end{array}$ \\
\hline $14-16$ & Пільга & $\begin{array}{l}\text { Тут вказуєте дані про отримані пільги. Ці колонки } \\
\text { будуть заповненні тільки по тих землях, щодо } \\
\text { яких встановлено пільги із сплати земподатку. у } \\
\text { них слід вказати: } \\
\text { - у к. } 14 \text { - код пільги. Берете його із Довідника } \\
\text { пільг, наведеного у листі ДФСУ від } 29.12 .2020 \text { р. } \\
\text { № 101/1 та 101/2; } \\
\text { - у к. } 15 \text { зазначаєте розмір пільги, тобто площу (у } \\
\text { га чи кв. м) земділянки, яка звільняється від } \\
\text { оподаткування, або відсоток звільненої від } \\
\text { земподатку площі; } \\
\text { - у к. } 16 \text { вказуєте суму пільги, тобто суму } \\
\text { земподатку, від сплати якої звільнено юрособу. } \\
\text { На суму пільги, вказану у к. 16, зменшують річну } \\
\text { суму земподатку. Якщо пільга стосується всієї } \\
\text { земділянки, то значення к. } 16 \text { дорівнює значенню } \\
\text { к. 13. }\end{array}$ \\
\hline 17 & $\begin{array}{lr}\text { Річна } & \text { сума } \\
\text { земельного } & \\
\text { податку } & \text { (до } \\
\text { сплати) } & \end{array}$ & $\begin{array}{l}\text { У цій графі відображають річну суму податку що } \\
\text { має бути сплачена до бюджету. Щоб } \\
\text { розрахувати розмір податку слід від показника к. } \\
13 \text { відняти показник к. } 16 . \\
\text { Розмір податку, яка вказана у цій колонці щодо } \\
\text { всіх земділнок підсумовується у ряд. } 2 \\
\text { переноситься до розд. ІІІ ряд. } 3 \text { к. } 3 .\end{array}$ \\
\hline
\end{tabular}




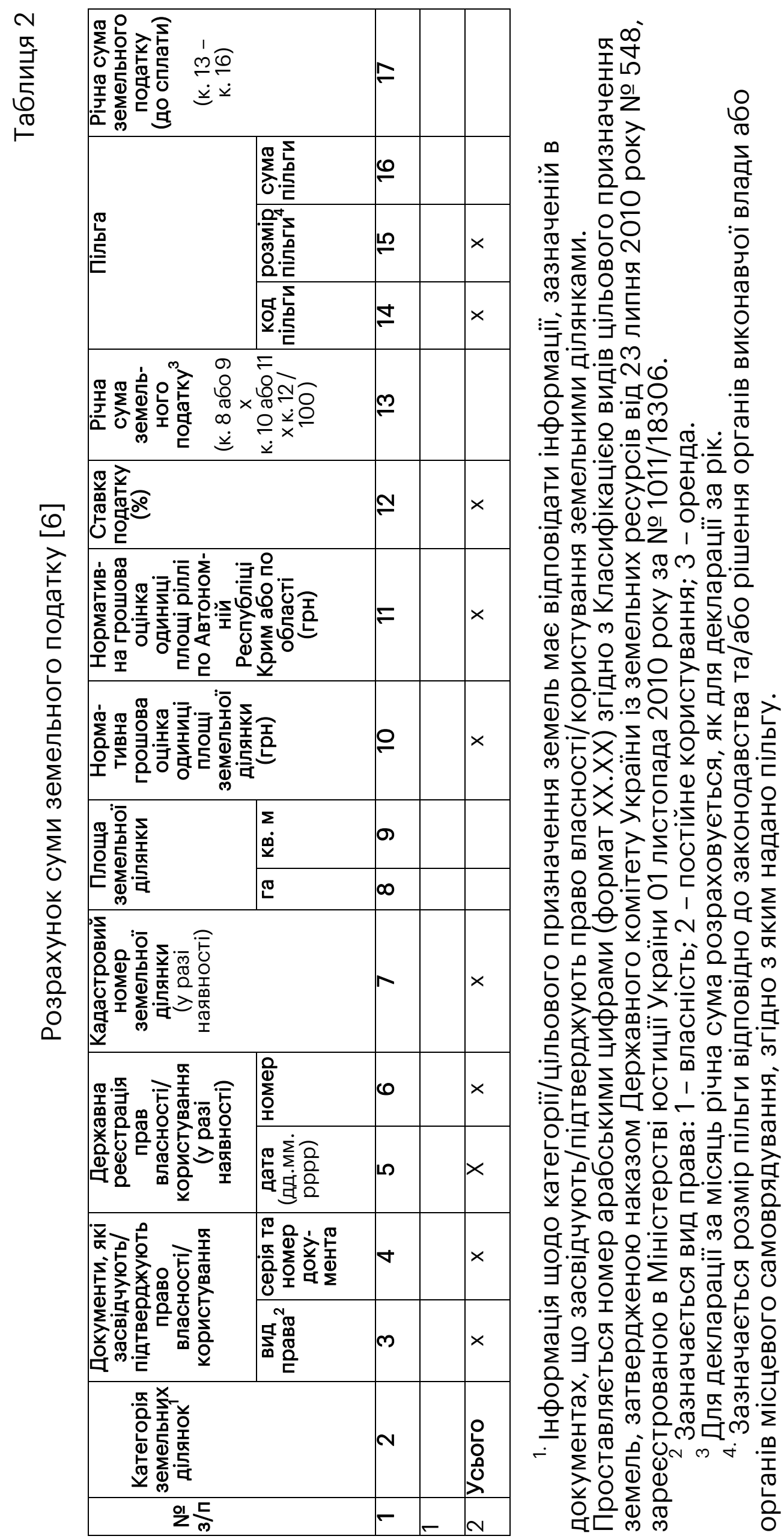


Отже, форма декларації побудована таким чином, що в одній декларації можна нарахувати податок тільки з однієї частини плати за землю. Тобто, якщо особа $є$ платником не тільки земельного податку, а й плати за землю, то доведеться заповнювати дві окремі декларації в частині цих складових плати за землю (наприклад: одна декларація щодо земельного оподаткування, а друга декларація щодо оренди земельної ділянки). Також, в одній декларації податок можна розрахувати тільки щодо земель, які знаходяться на одній території, тобто мають один і той самий код КОАТУУ.

Спираючись, на аналіз чинного законодавства, необхідно зазначити, що $€$ певні категорії осіб та певні категорії земель, які звільняються від сплати за землю.

Так, згідно ст. 281 ПКУ, від сплати земельного податку звільняються [8]:

- інваліди першої і другої групи; років;

- фізичні особи, які виховують трьох і більше дітей віком до 18

- пенсіонери (за віком);

- ветерани війни та особи, на яких поширюється дія Закону України «Про статус ветеранів війни, гарантії їх соціального захисту»;

- фізичні особи, визнані законом особами, які постраждали внаслідок Чорнобильської катастрофи.

Звільнення від сплати податку за земельні ділянки, передбачене для відповідної категорії фізичних осіб, поширюється на земельні ділянки за кожним видом використання у межах граничних норм [9]:

- для ведення особистого селянського господарства - у розмірі не більш як 2 гектари;

- для будівництва та обслуговування житлового будинку, господарських будівель і споруд (присадибна ділянка): у селах - не більш як 0,25 гектара, в селищах - не більш як 0,15 гектара, в містах не більш як 0,10 гектара;

- для індивідуального дачного будівництва - не більш як 0,10 гектара;

- для будівництва індивідуальних гаражів - не більш як 0,01 гектара;

- для ведення садівництва - не більш як 0,12 гектара.

Від сплати податку звільняються на період дії єдиного податку четвертої групи власники земельних ділянок, земельних часток (паїв) та землекористувачі за умови передачі земельних ділянок та земельних часток (паїв) в оренду платнику єдиного податку четвертої групи [8].

Також, у ст. 283 Податкового кодексу України визначено земельні ділянки, які не підлягають оподаткуванню земельним податком, а саме:

- сільськогосподарські угіддя зон радіоактивно забруднених територій, визначених відповідно до закону такими, що зазнали радіоактивного забруднення внаслідок Чорнобильської катастрофи (зон відчуження, безумовного (обов'язкового) відселення, гарантованого добровільного відселення і посиленого радіоекологічного контролю), і хімічно забруднених 
сільськогосподарських угідь, на які запроваджено обмеження щодо ведення сільського господарства;

- землі сільськогосподарських угідь, що перебувають у тимчасовій консервації або у стадії сільськогосподарського освоєння;

- земельні ділянки державних сортовипробувальних станцій і сортодільниць, які використовуються для випробування сортів сільськогосподарських культур;

землі дорожнього господарства автомобільних доріг загального користування - землі під проїзною частиною, узбіччям, земляним полотном, декоративним озелененням, резервами, кюветами, мостами, штучними спорудами, тунелями, транспортними розв'язками, водопропускними спорудами, підпірними стінками, шумовими екранами, очисними спорудами і розташованими в межах смуг відведення іншими дорожніми спорудами та обладнанням, а також землі, що знаходяться за межами смуг відведення, якщо на них розміщені споруди, що забезпечують функціонування автомобільних доріг, а саме:

а) паралельні об'їзні дороги, поромні переправи, снігозахисні споруди і насадження, протилавинні та протисельові споруди, вловлюючі з'їзди, захисні насадження, шумові екрани, очисні споруди;

б) майданчики для стоянки транспорту і відпочинку, склади, гаражі, резервуари для зберігання паливно-мастильних матеріалів, комплекси для зважування великогабаритного транспорту, виробничі бази, штучні та інші споруди, що перебувають у державній власності, власності державних підприємств або власності господарських товариств, у статутному капіталі яких 100 відсотків акцій (часток, паїв) належить державі;

- земельні ділянки сільськогосподарських підприємств усіх форм власності та фермерських (селянських) господарств, зайняті молодими садами, ягідниками та виноградниками до вступу їх у пору плодоношення, а також гібридними насадженнями, генофондовими колекціями та розсадниками багаторічних плодових насаджень;

- земельні ділянки кладовищ, крематоріїв та колумбаріїв.

- земельні ділянки, на яких розташовані дипломатичні представництва, які відповідно до міжнародних договорів (угод), згода на обов'язковість яких надана Верховною Радою України, користуються приміщеннями та прилеглими до них земельними ділянками на безоплатній основі.

- земельні ділянки, надані для будівництва і обслуговування культових та інших будівель, необхідних для забезпечення діяльності релігійних організацій України, статути (положення) яких зареєстровано у встановленому законом порядку.

Висновки та перспективи подальших досліджень. Таким чином, земля - це найцінніше багатство країни. Тому, в межах державної політики відбувається побудова системи управління земельними ресурсами, яка покликана на ії раціональне використання. Одним 3 інструментів управління земельними ресурсами $€$ сплата земельного податку. Особливості та механізм сплати земельного податку визначено чинним законодавством України, зокрема Податковим кодексом України. Платниками земельного податку $є$ як фізичні, так і юридичні особи. Відповідно до чинного законодавства, також визначено категорію осіб та земель, які $€$ пільговими категоріями та звільняються від сплати земельного податку. 


\section{Література:}

1. Павалій А. С. Аналіз системи земельного оподаткування в Україні. URL:http://www.vestnik-econom.mgu.od.ua/journal/2015/142015/61.pdf.

2. Податковий кодекс України. URL:https://zakon.rada.gov.ua/la ws/show/2755-17\#Text.

3.Борзенкова О.Д. Земельне оподаткування в Україні: аналіз сучасного стану та перспективи. URL:http://globalnational.in.ua/archive/8-2015/08-1.pdf.

4. Білоус-Осінь Т., Койчева О. Теоретико-правові аспекти адміністрування земельного податку. Юридичний вісник, 2019. №3. С. 31-37.

5. Тронько О.В. Ретроспектива адміністрування земельного податку в Україні: історичні та сучасні аспекти. Науковий вісник публічного та приватного права, 2017. №2. С. 28-33.

6. Децюра С. Земельний податок - 2021: нарахування. Податки і бух облік, 2021. №8. URL:https://i.factor.ua/ukr/journals/nibu/2021/jan uary/issue-8/article-113086.html.

7. Земельний податок - 2021: пам'ятка від ДПС. URL:http://www.visnuk.com.ua/uk/news/100022230-zemelniypodatok-2021-pamyatka-vid-dps.

8. Земельний податок 3 фізичних осіб: ДПС про порядок визначення та сплати. URL:http://www.visnuk.com.ua/uk/news/10002 2956-zemelniy-podatok-z-fizichnikh-osib-dps-pro-poryadokviznachennya-ta-splati.

9.Брикайло Ю. Земельний податок 2021: ставки, пільги, відповідальність. URL: https://dreamdim.ua/ru/zemelnyj-podatok$\underline{2021 / .}$

\section{References:}

1. Pavalij A. S. Analiz systemy zemeljnogho opodatkuvannja $v$ Ukrajini. URL:http://www.vestnik-econom.mgu.od.ua/journal/2015/142015/61.pdf.

2. Podatkovyj kodeks Ukrajiny. URL:https://zakon.rada.gov.ua/l aws/show/2755-17\#Text.

3. Borzenkova O. D. Zemeljne opodatkuvannja v Ukrajini: analiz suchasnogho stanu ta perspektyvy. URL:http://globalnational.in.ua/archive/8-2015/08-1.pdf.

4. Bilous-Osinj T., Kojcheva O. Teoretyko-pravovi aspekty administruvannja zemeljnogho podatku. Jurydychnyj visnyk, 2019. \#3. S. 31-37.

5. Tronjko O. V. Retrospektyva administruvannja zemeljnogho podatku $v$ Ukrajini: istorychni ta suchasni aspekty. Naukovyj visnyk publichnogho ta pryvatnogho prava, 2017. \#2. S. 28-33.

6. Decjura S. Zemeljnyj podatok - 2021: narakhuvannja. Podatky i bukh oblik, $2021 . \quad$ URL:https://i.factor.ua/ukr/journals/nibu/2021/january/issue-8/article113086.html.

7. Zemeljnyj podatok - 2021: pom'jatka vid DPS. URL:http://www.visnuk.com.ua/uk/news/100022230-zemelniypodatok-2021-pamyatka-vid-dps.

8. Zemeljnyj podatok $\mathrm{z}$ fizychnykh osib: DPS pro porjadok vyznachennja ta splaty. URL:http://www.visnuk.com.ua/uk/news/10002 
2956-zemelniy-podatok-z-fizichnikh-osib-dps-pro-poryadokviznachennya-ta-splati.

9. Brykajlo Ju. Zemeljnyj podatok 2021: stavky, piljghy, vidpovidaljnistj. URL: https://dreamdim.ua/ru/zemelnyj-podatok-2021/.

The article is devoted to the study of the peculiarities of land taxation in Ukraine. The paper notes that the system of land taxation in Ukraine began to take shape in 1992 with the adoption of the Law of Ukraine "On Payment for Land". It is determined that one of the effective tools of the state's influence on land relations is the payment for land. It is substantiated that revenues from land taxation are an integral source of filling the state and local budgets. According to the current legislation, land taxation can be expressed through such categories as: land tax, land purchase and registration tax, land use tax.The economic content of land taxation includes the following functions: incentives, regulation, fiscal. It is noted that the payers of land tax are the owners of land plots, shares (units), namely: individuals (citizens), legal entities, natural persons-entrepreneurs. The law stipulates that legal entities and natural persons-entrepreneurs must pay this tax monthly, within 30 calendar days, and natural persons (citizens) - within 60 days from the date of delivery of the tax noticedecision. The algorithm of land tax calculation is revealed and it is determined that it depends on the rules of determining the land tax base, namely on whether the normative monetary valuation of land is carried out or not.The normative values of land tax payment in 2021 are given on the example of Donetsk region. It is emphasized that in order for legal entities to report on land tax, it is necessary to submit a declaration, which is approved by the order of the Ministry of Finance dated 16.06.2015 № 560. Features and rules of the declaration are given in the work. Based on the analysis of the current legislation, it is noted that there are certain categories of persons and certain categories of land that are exempt from payment for land.

Thus, the analysis of the features of land taxation, allowed to determine the important economic and regulatory role of land tax for the formation of local and state budgets, as well as the modern mechanism and tools for paying land tax. 